\title{
Penggunaan Fuzzy Logic \& Metode Mamdani untuk Menghitung Pembelian, Penjualan dan Persediaan
}

\author{
Maria Yus Trinity Irsan \\ maria.irsan@president.ac.id \\ Actuarial Science Study Program, Faculty of Business \\ Universitas Presiden, Cikarang, Indonesia \\ Matius Irsan Kasau \\ matius.irsan@gmail.com \\ Kopertis IX DPK STMIK Dipanegara \\ Ika Pratiwi Simbolon \\ ika.pratiwi@president.ac.id \\ Accounting Study Program, Faculty of Business \\ Universitas Presiden, Cikarang, Indonesia
}

\begin{abstract}
Fuzzy Logic is a development of Binary Logic that can be used to analyze data in research in both the exact and social fields. In this study, fuzzy logic is used to analyze data in a "Ayam Goreng Murah Rezeki" restaurant related to three linguistic attributes, each of which consists of two linguistic variables: Inventory (Little, Many), Sales (Down, Up), and Purchases (Reduced, Increased) using the Mamdani method. The purpose of the study is to provide an input value of Inventory and Sales to get a Purchase output value. The results of data analysis using a linear down graph and a linear upward graph on each linguistic variable with the Mamdani method yield results in the estimated area or range.
\end{abstract}

Keywords: Fuzzy Logic, Inventory, Mamdani, Purchase, Sales

\begin{abstract}
Abstrak
Fuzzy Logic merupakan pengembangan dari Binary Logic yang dapat digunakan untuk menganalisis data dalam Penelitian baik bidang eksakta maupun bidang sosial. Pada penelitian ini, fuzzy logic digunakan untuk menganalisis data pada sebuah Rumah Makan "Ayam Goreng Murah Rezeki" berkaitan dengan tiga atribut linguistik yang masing masing terdiri atas dua variabel lingustik: Persediaan (Sedikit,Banyak), Penjualan(Turun,Naik) dan Pembelian (Berkurang, Bertambah) menggunakan metode Mamdani. Adapun tujuan penelitian adalah memberikan suatu nilai input Persediaan dan Penjualan untuk mendapatkan suatu nilai output Pembelian. Hasil analisis data menggunakan grafik linier turun dan grafik linier naik pada masing masing variabel linguistik dengan metode Mamdani memberikan hasil dalam wilayah atau range yang diperkirakan.
\end{abstract}

Kata Kunci: Fuzzy Logic, Persediaan, Mamdani, Pembelian, Penjualan 


\section{PENDAHULUAN}

Fuzzy Logic atau Logika Samar pertama kali diperkenalkan oleh Professor Lotfi A. Sodeh dari California, USA pada tahun 1965 (Susilo \& SJ, 2006) (Setiadi, 2009). Fuzzy Logic memanfaatkan wilayah antara 0 dan 1 yang tidak dikenal dalam Binary Logic atau Logika Biner, atau dengan perkataan lain 0 dan 1 adalah Logika Biner, sedangkan 0 sampai 1 adalah Logika Samar. Wilayah antara 0 dengan 1 dalam Logika Samar merupakan wilayah abu abu, atau wilayah samar, atau wilayah tidak tegas dengan range 0 persen sampai 100 persen (Susilo,2006). Wilayah ini dapat dimanfaatkan untuk menyatakan dua atau lebih keadaan berada pada saat yang sama dengan kadar atau tingkat yang sama atau berbeda, misalnya "salah" dan "benar" hadir pada saat yang sama dengan tingkat atau kadar "salah" 15 persen dan tingkat atau kadar "benar" 85 persen, atau tingkat yang lainnya.

Berkat keluwesan dari Fuzzy Logic ini, menyebabkan dapat digunakan secara luas baik dalam bidang eksakta, maupun dalam bidang sosial. Caranya adalah menetapkan sejumlah kelompok fungsi linguistik yang saling bergantungan, dan setiap fungsi linguistik dibagi menjadi beberapa variabel linguistik dengan nilai keanggotaan tertentu, misalnya fungsi linguistik "TEMPERATUR" dapat dibagi menjadi dua, tiga, empat, atau yang lainnya variabel linguistik "DINGIN" dan "PANAS", atau "DINGIN", "SEJUK", dan "PANAS", atau "DINGIN", "SEJUK", "NORMAL, dan "PANAS", atau yang lainnya. Selanjutnya setiap variabel linguistik ini diberi nilai keanggotaan, misalnya untuk yang empat variabel: PANAS dengan nilai keanggotaan 0 derajat Celcius sampai 20 derajat Celcius, SEJUK dengan nilai keanggotaan 10 derajat sampai 30 derajat, NORMAL dengan nilai keanggotaan 20 derajat Celcius sampai 40 derajat Celcius, dan 30 derajat ke atas adalah nilai keanggotaan dari variabel linguistik PANAS. Masing masing variabel linguistik ini memiliki derajat atau tingkat keanggotaan dari 0 persen sampai 100 persen (S, 1999).

Tulisan ini mengambil fungsi linguistik PEMBELIAN, PENJUALAN, dan PERSEDIAAN ayam potong pada Rumah Makan "AYAM GORENG MURAH REZEKI" yang beralamat di Jl. Perumnas Raya, Bumi Sudiang Permai Blok G No. 41 Daya, Sudiang, Makassar. Masing masing atribut linguistik tersebut dibagi menjadi dua variabel linguistik: PEMBELIAN dengan variabel linguistik BERKURANG dan BERTAMBAH, variabel linguistik PENJUALAN dengan variabel linguistik TURUN dan NAIK, variabel linguistik PERSEDIAAN dengan variabel linguistik SEDIKIT dan BANYAK. Adapun nilai keanggotaan dan tingkat atau derajat keanggotaan akan dibahas lebih lanjut pada Bab selanjutnya.

Untuk penarikan kesimpulan (inferensi) dalam fuzzy logic dapat digunakan setidaknya tiga pilihan metode yakni: Metode Tsukamoto, Metode Mamdani, atau Metode Sugeno. Ketiga metode ini memiliki kesamaan dalam hal tahapan, mulai dari fuzzyfikasi, operasi fuzzy logic, implikasi, agregasi, sampai pada tahap akhir defuzzyfikasi. Perbedaannya terlertak hanya pada tahap akhir defuzzyfikasi. Inferensi pada metode Tsukamoto dilakukan proses implikasi dengan metode fungsi MIN, yang daripadanya didapatkan nilai yang disebut dengan alpha predikat, yang selanjutnya diperoleh nilai output yang dicari. Inferensi pada metode Mamdani dilakukan proses implikasi dengan metode fungsi MIN, dan proses komposisi aturannya dengan menggunakan fungsi MAX, yang selanjutnya diperoleh nilai output yang dicari dengan metode Centroid (Suardika \& dkk, 2018). Sedangkan inferensi pada metode Sugeno mirip dengan metode Tsukamoto, perbedaan terletak pada cara mendapatkan alpa predikat. Tanpa menunjukkan dan mempertimbangkan berbagai kelebihan dan kekurangan masing-masing metode, tulisan ini membatasi hanya pada Metode Mamdani, terlepas dari kelebihan dan kekurangannya dibandingkan dua metode lainnya tersebut. 


\section{Batasan dan Rumusan Masalah, Tujuan dan Manfaat Penelitian}

Berbicara berbisnis Rumah Makan, terdapat banyak masalah dalam pengelolaannya antara lain: Masalah Tempat dan Lokasi, Masalah Tenaga Kerja, Masalah Konsumen, Masalah Pembelian berbagai kebutuhan komoditas seperti; Kebutuhan akan beras, kebutuhan akan rempah rempah, masalah ayam potong, masalah pasar dan pemasaran dan sebagainya. Tulisan ini batasan masalahnya hanya meneliti khusus masalah ayam potong tentang Pembelian, Penjualan, dan Persediaan dengan rumusan masalah bagaimana merancang sistem fuzzy logic yang dapat menghitung suatu variabel linguistik jika variabel linguistik lainnya diketahui menggunakan metode Mamdani. Adapun yang menjadi tujuan penelitian adalah merancang grafik fungsi fungsi keanggotaan setiap variabel linguistik pada atribut linguistik yang terkait satu sama lain. Sedangkan manfaat penelitian adalah untuk memudahkan pihak pengelola untuk menetapkan jumlah ayam potong yang harus dibeli pada suatu hari berdasarkan data penjualan dan persediaan yang ada pada saat itu.

\section{KAJIAN PUSTAKA}

Untuk menganalisis keterkaitan hubungan antar variabel linguistik, beberapa fungsi keanggotaan fuzzy logic yang sering digunakan adalah: fungsi linier naik, fungsi linier turun, fungsi segi tiga, fungsi trapisiun, fungsi pertumbuhan $S$, fungsi penyusutan $S$, fungsi lonceng PI atau Beta. Tulisan ini memilih fungsi linier turun untuk variabel linguistik BERKURANG, TURUN, SEDIKIT dan fungsi linier naik untuk variabel linguistik BERTAMBAH, NAIK, BANYAK. Secara umum fungsi keanggotaan linier turun dapat digambarkan sebagai berikut (Setiaji,2009):

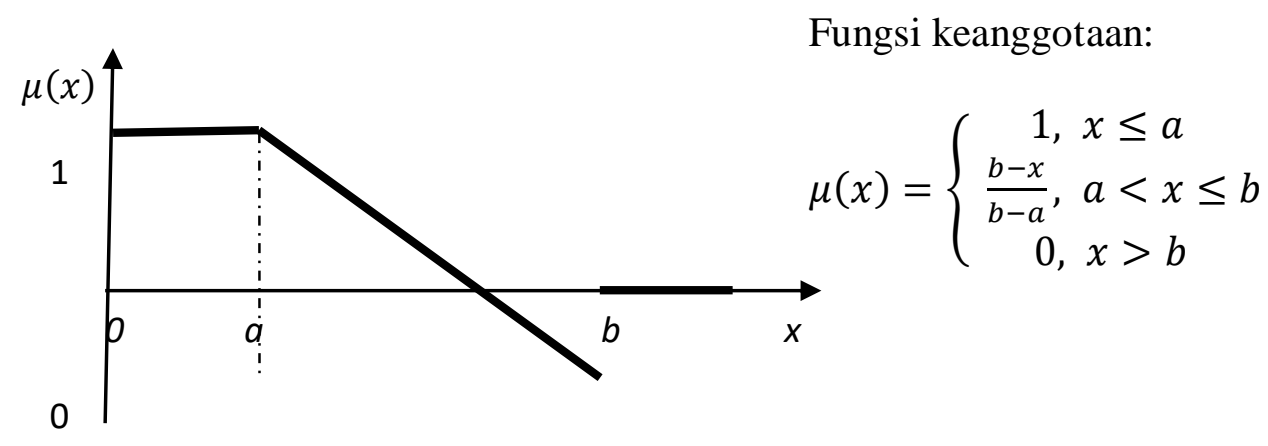

Gambar 1. Grafik dan Persamaan Fungsi Keanggotaan Linier Turun

Perhatikan Gambar 1, nilai keanggotaan (sumbu x) terbagi atas tiga wilayah domain antara 0 dengan $a$, antara $a$ dengan $b$, dan antara $b$ dengan tak terhingga. Masing masing nilai keanggotaan ini memiliki tingkat atau derajat keanggotaan tersendiri. Nilai keanggotaan antara 0 dengan $a$ tingkat atau derajat keanggotaannya satu (1), nilai keanggotaan antara $a$ dengan $b$ tingkat atau derajat keanggotaannya tersebar antara nol (0) dengan satu (1), nilai keanggotaan diatas $b$ tingkat atau derajat keanggotaannya nol (0). Sebagai contoh jika $a=15$ dan $b=30$, maka berdasarkan persamaan (1) untuk nilai keanggotaan 20 yang terletak antara $a$ dengan $b$ memiliki tingkat atau derajat keanggotaan $\frac{30-20}{30-15}=\frac{2}{3}$. dan fungsi keanggotaan linier naik dapat digambarkan sebagai berikut: 


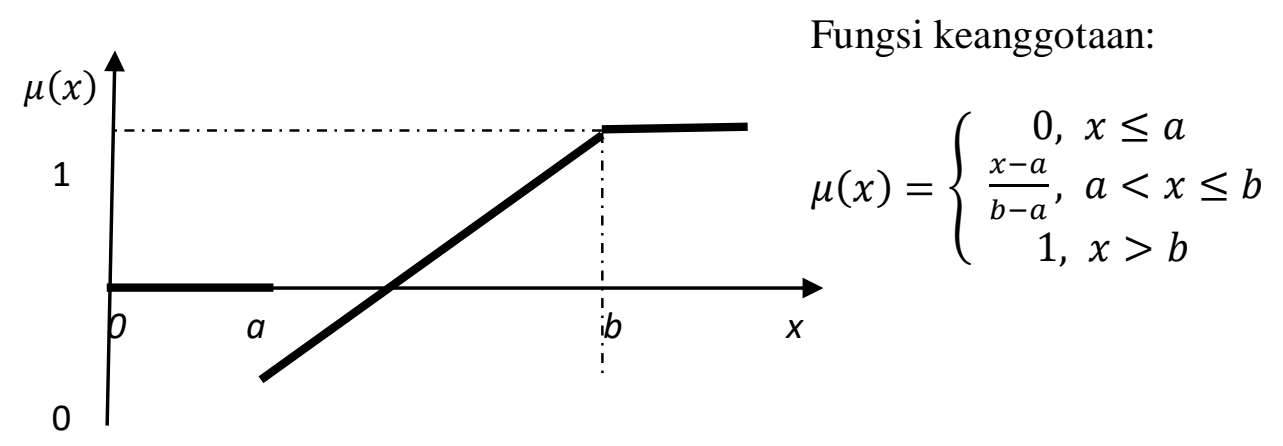

Gambar 2. Grafik dan Persamaan Fungsi Keanggotaan Linier Naik

Seperti pada Gambar 1, pada Gambar 2 ini nilai keanggotaan (sumbu x) terbagi atas tiga wilayah domain antara 0 dengan $a$, antara $a$ dengan $b$, dan antara $b$ dengan tak terhingga. Masing masing nilai keanggotaan ini memiliki tingkat atau derajat keanggotaan tersendiri. Nilai keanggotaan antara 0 dengan $a$ tingkat atau derajat keanggotaannya nol (0), nilai keanggotaan antara $a$ dengan $b$ tingkat atau derajat keanggotaannya tersebar antara nol $(0)$ dengan satu (1), nilai keanggotaan diatas $b$ tingkat atau derajat keanggotaannya satu (1). Sebagai contoh jika $a=15$ dan $b=30$, maka berdasarkan persamaan (2) untuk nilai keanggotaan 20 yang terletak antara $a$ dengan $b$ memiliki tingkat atau derajat keanggotaan $\frac{20-15}{30-15}=\frac{1}{3}$.

Gambar 1 digunakan untuk menyatakan variabel linguistik BERKURANG pada Pembelian, TURUN pada Penjualan, dan SEDIKIT pada Persediaan. Sementara Gambar 2 digunakan untuk menyatakan variabel linguistik BERTAMBAH pada Pembelian, NAIK pada Penjualan, dan BANYAK pada Persediaan.

Perpaduan Gambar 1 dan Gambar 2 diperoleh seperti Gambar 3.

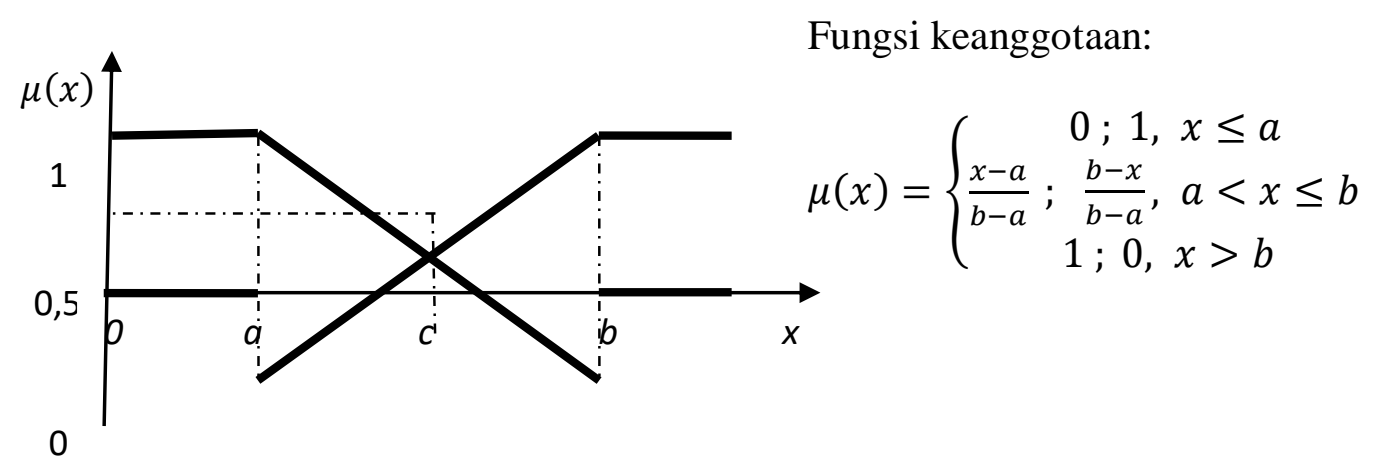

Gambar 3. Grafik dan Persamaan Fungsi Keanggotaan Gabungan Gambar 1 dan Gambar 2

Perhatikan bahwa pada nilai keanggotaan $c=\frac{a+b}{2}$ perpotongan antara grafik turun dan grafik naik memiliki derajat keanggotaan yang sama besarnya yaitu nol koma lima $(0,5)$. Nilai keanggotaan antara $a$ dengan $c$ memiliki derajat keanggotaan grafik turun di atas 0,5 lebih tinggi daripada derajat keanggotaan grafik naik di bawah 0,5. Sebaliknya, nilai keanggotaan antara $c$ dengan $b$ memiliki derajat keanggotaan grafik turun di bawah 0,5 lebih rendah daripada derajat keanggotaan grafik naik di atas 0,5 . Perlu diingat bahwa jumlah derajat keanggotaan suatu nilai keanggotaan dari grafik turun dengan grafik naik selalu sama dengan satu (1). Sebagai contoh untuk $a=15$ dan $b=30 \quad$ seperti yang dicontohkan diatas untuk nilai keanggotaan 20 derajat keanggotaannya $\frac{2}{3}$ untuk grafik turun, dan $\frac{1}{3}$ untuk grafik naik, 
jumlahnya adalah satu (1). Demikian juga untuk seluruh nilai keanggotaan lainnya selalu berjumlah sama dengan satu.

Mamdani atau lengkapnya Ebrahim H. Mamdani memanfaatkan perbedaan dari dua nilai ini untuk membentuk metodenya yang dikenal dengan Metode Mamdani. Hasil kombinasi derajat keanggotaan dari berbagai nilai keanggotaan diperoleh sejumlah nilai derajat keanggotaan MINIMUM (MIN). Dari sejumlah nilai MIN ini terdapat satu yang nilainya MAXIMUM (MAX) diantara nilai nilai MIN tersebut, yang digunakan untuk menghitung nilai defuzzyfikasi yang dicari. Itulah sebabnya metode Mamdani dikenal pula dengan metode MINMAX artinya nilai MAX dari sejumlah nilai MIN (S, 1999).

Selanjutnya, perlu mengetahui pula beberapa definisi dan langkah langkah yang dibutuhkan dalam fuzzy logic sebagai berikut:

Beberapa definisi:

a. Fuzzy Set yaitu kumpulan nilai yang mewakili suatu kondisi tertentu dalam suatu variabel fuzzy dengan nilai antara 0 dengan 1 . Nilai ini disebut derajat keanggotaan.

b. Fuzzy Variable yaitu suatu notasi berupa karakter atau simbol yang mewakili sejumlah nilai yang tidak tentu dalam suatu sistem fuzzy.

c. Union or Universe yaitu keseluruhan (semesta) pembicaraan berupa nilai yang diperkenankan untuk dioperasikan dalam suatu himpunan fuzzy.

d. Domain yaitu subbagian dari union yang diijinkan untuk dioperasikan, atau dengan perkataan lain suatu wilayah nilai keanggotaan tertentu dalam suatu himpunan fuzzy.

e. Member Function yaitu grafik yang menyatakan hubungan antara nilai keanggotaan dengan derajat keanggotaan dalam suatu himpunan fuzzy.

f. Linguistic yaitu NAMA yang diberikan pada suatu Entitas atau bagian bagian dari suatu Entitas dalam suatu himpunan fuzzy.

Langkah-langkah dalam fuzzy logic (Dewi \& Hari, 2010):

Langkah 1: Fuzzyfikasi yaitu suatu nilai keanggotaan dikonversi ke suatu derajat keanggotaan melalui grafik fungsi keanggotaan.

Langkah 2: Operasi fuzzy logic yaitu operasi yang menggunakan gerbang logika AND, OR, NOT dengan masukan dua nilai derajat keanggotaan (anteseden 1 dan anteseden 2), diperoleh derjat kebenaran MIN atau MAX.

Langkah 3: Implikasi yaitu merupakan fungsi IF-THEN Rule atau aturan JIKA-MAKA, menerima dua masukan berupa derajat kebenaran dari bagian Anteseden dan fuzzy set dari bagian Konsekuen.

Langkah 4: Agregasi/Komposisi yaitu mencari nilai MIN diantara nilai MAX, atau nilai MAX diantara nilai MIN. Masukannya berupa dua kelompok himpunan Kaidah Fuzzy OR, AND, NOT dengan IF-THEN Rule diperoleh sebuah Fuzzy Set Tunggal, MAX (OR) atau MIN (AND), atau hasil dari operasi NOT.

Langkah 5: Defuzzyfikasi yaitu proses menghitung suatu nilai crisp (nilai keanggotaan) yang dicari menggunakan dua masukan berupa sejumlah derajat keanggotaan dan sejumlah fungsi keanggotaan.

Perlu diketahui bahwa operasi AND hasilnya adalah MIN, operasi OR hasilnya adalah MAX, dan operasi NOT hasilnya adalah 1 dikurang dengan yang di NOT kan. 


\section{METODE PENELITIAN}

\section{Sumber dan Jenis Data}

Penelitian ini menggunakan data primer yang dicatat setiap hari selama satu minggu dari Rumah Makan "AYAM GORENG MURAH REJEKI" yang beralamat di Jl. Sudiang Raya Blok G No. 41 Perumahan Bumi Sudiang Permai (BSP) Kelurahan Paccerakkang, Kecamatan Biringkanaya, Daya Kota Makassar, Provinsi Sulawesi Selatan. Dalam seminggu operasi selama 7 hari, Rumah Makan ini menghabiskan rata rata 500 ekor ayam potong, terendah 50 ekor ayam potong dan tertinggi 102 ekor ayam potong sehari dengan rincian lengkap periode tanggal 4 sampai tanggal 10 bulan Februari 2019 sebagai berikut:

Tabel 1. Data Kebutuhan dan Persediaan Ayam Potong per Hari selama Seminggu

\begin{tabular}{|c|rc|c|c|}
\hline Hari & Tanggal & Persediaan & Dibutuhkan \\
\hline Senin & 4 & Februari 2019 & 20 ekor & 67 ekor \\
Selasa & 5 & Februari 2019 & 15 ekor & 79 ekor \\
Rabu & 6 & Februari 2019 & 25 ekor & 93 ekor \\
Kamis & 7 & Februari 2019 & 10 ekor & 50 ekor \\
Jum'at & 8 & Februari 2019 & 35 ekor & 63 ekor \\
Sabtu & 9 Februari 2019 & 12 ekor & 98 ekor \\
Minggu & 10 Februari 2019 & 17 ekor & 100 ekor \\
\hline Total/Rata-Rata & ----- & ------ & 500 ekor/71 ekor \\
\hline
\end{tabular}

Sumber: Data satu Minggu RM “Ayam Goreng Murah Rezeki”

\section{Metode Analisis Data}

Menggunakan metode Mamdani atau metode MIN-MAX. Pertama tama menyatakan setiap linguistik dan variabel linguistik ke dalam fungsi keanggotaan masing masing, kemudian diproses mengunakan lima langkah yang telah dijelaskan pada Kajian Pustaka.

\section{Definisi Operasional Variabel}

Adapun operasional variabel yang digunakan didefinisikan sebagai berikut:

a. PEMBELIAN adalah suatu atribut linguistik yang menyatakan jumlah ayam potong yang harus dibeli setiap hari dengan variabel linguistik BERKURANG dan BERTAMBAH.

b. PENJUALAN adalah suatu atribut linguistik yang menyatakan jumlah ayam potong yang harus disiapkan bagi Pelanggan setiap hari dengan variabel linguistik TURUN atau NAIK.

c. PERSEDIAAN adalah suatu atribut linguistik yang menyatakan jumlah ayam potong yang masih tersedia bagi Pelanggan setiap hari dengan variabel linguistik SEDIKIT atau BANYAK.

Ketiga operasional variabel ini saling berhubungan dan saling bergantungan yang akan dinyatakan dalam grafik fungsi keanggotaan masing masing. Selanjutnya, analisis data dilakukan dengan langkah langkah sebagai berikut:

1. Menentukan RANGE dan Fungsi keanggotaan dari masing masing atribut linguistik: PEMBELIAN, PENJUALAN, dan PERSEDIAAN berdasarkan data yang telah didapat pada Rumah Makan "AYAM GORENG MURAH REZEKI".

2. Menentukan fungsi pada KONSEKUEN untuk masing masing aturan Implikasi pada metode Mamdani yang digunakan.

3. Membentuk aturan Implikasi fuzzy dengan mengkombinasikan setiap atribut linguistik pada setiap variabel input.

4. Melakukan defuzzyfikasi dengan menghitung rata rata terbobot dari semua aturan implikasi fuzzy. 
5. Melakukan simulasi Fuzzy Inference System (FIS) metode Mamdani untuk menentukan ketepatan jumlah produksi ayam potong.

6. Menghitung nilai MAPE untuk menentukan keakuratan dari FIS yang digunakan.

\section{HASIL DAN PEMBAHASAN}

\section{Penetapan RANGE Atribut Linguistik}

Berdasarkan data yang disajikan pada Tabel 1 dapat ditetapkan RANGE dari masing masing Atribut Linguistik sebagai berikut:

Range untuk atribut linguistik Penjualan:

Variabel Linguistik BERKURANG : 100 ekor berkurang hingga 50 ekor

Variabel Linguistik BERTAMBAH : 50 ekor bertambah hingga 100 ekor

Range untuk atribut linguistik Pembelian:

Variabel Linguistik TURUN : 90 ekor menurun hingga 65 ekor

Variabel Linguistik NAIK : 65 ekor meningkat hingga 90 ekor

Range untuk atribut linguistik Persediaan:

Variabel Linguistik SEDIKIT : 35 ekor mengecil hingga 10 ekor

Variabel Linguistik BANYAK : 10 ekor membesar hingga 35 ekor

Range atribut Penjualan dan Persediaan ditetapkan berdasarkan data maksimum dan data minimum pada Tabel 1, sedangkan range atribut Pembelian ditetapkan dengan mengurangkan nilai tertinggi pada Penjualan yaitu 100 ekor dengan nilai terendah pada atribut Persediaan yaitu 10 ekor, diperoleh 90 ekor sebagai batas tertinggi, dan mengurangkan nilai tertinggi pada Penjualan yaitu 100 ekor dengan nilai tertinggi pada atribut Persediaan yaitu 35 ekor, diperoleh 65 ekor sebagai batas terendah.

\section{Grafik Fungsi Keanggotaan}

Setelah batas terendah dan batas tertinggi diketahui, selanjutnya grafik fungsi keanggotaan dapat digambarkan seperti Gambar 4, Gambar 5, dan gambar 6 sebagai berikut:

Untuk Atribut Pembelian:

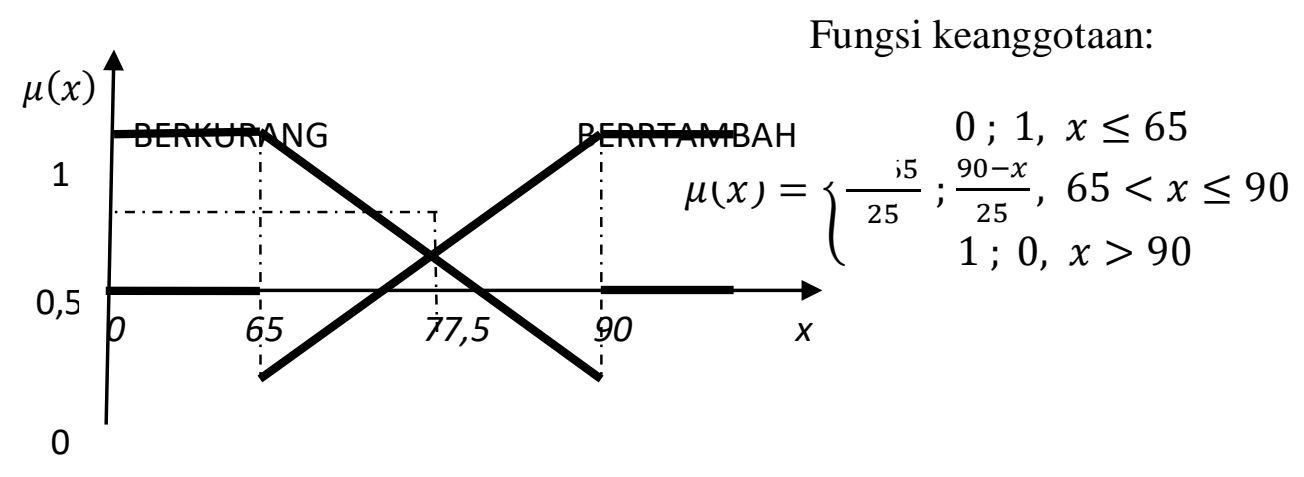

Gambar 4 Grafik dan Persamaan Fungsi Keanggotaan Atribut Pembelian 
Untuk Atribut Penjualan:

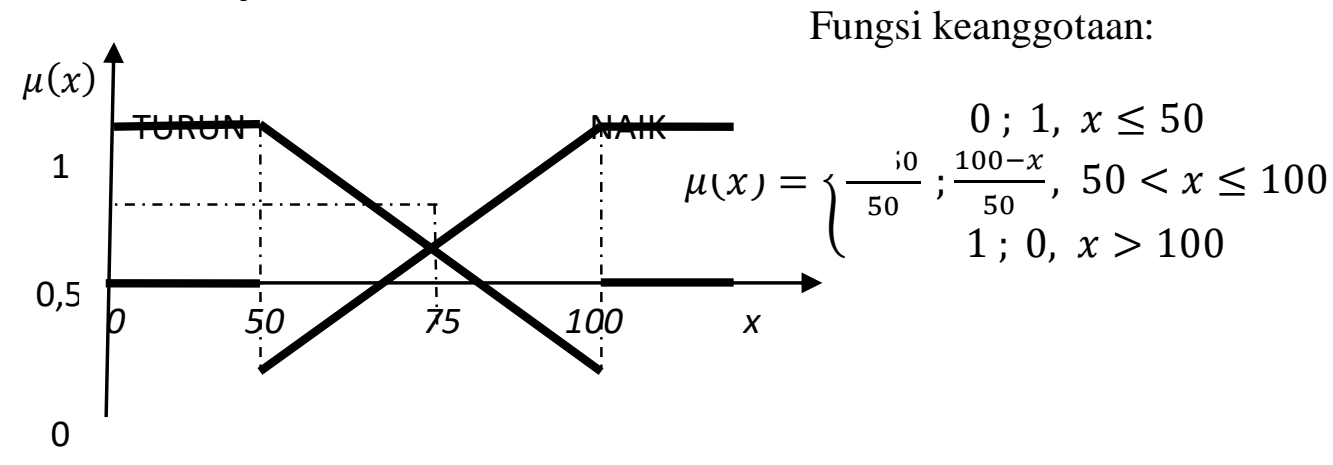

Gambar 5. Grafik dan Persamaan Fungsi Keanggotaan Atribut Penjualan.

Untuk Atribut Persediaan:

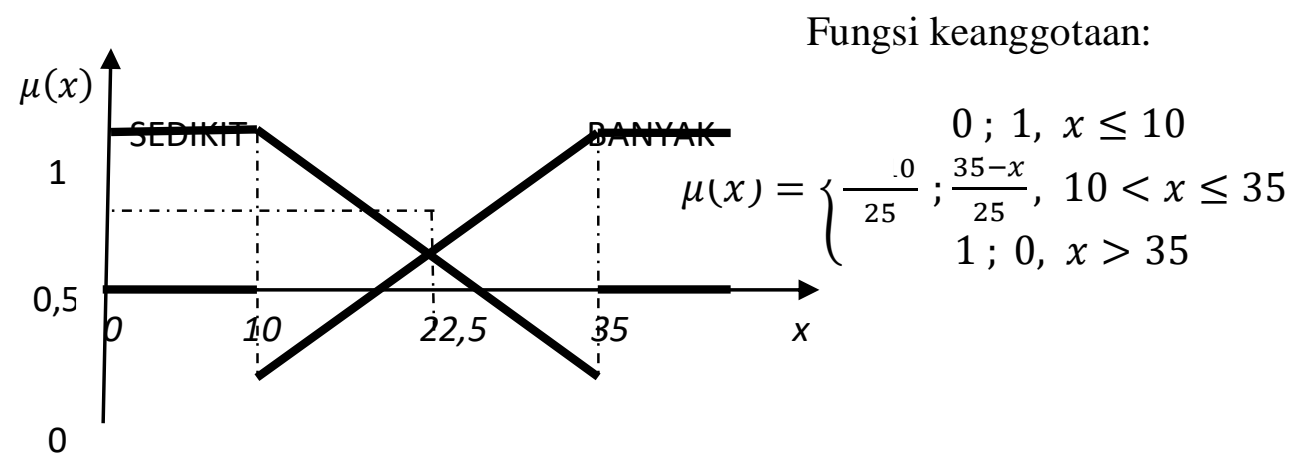

Gambar 6. Grafik dan Persamaan Fungsi Keanggotaan Atribut Persediaan.

Perhatikan bahwa ketiga grafik fungsi keanggotaan adalah mirip, yang berbeda hanya batas batas dari nilai keanggotaan masing masing variabel lingustik setiap atribut linguistik.

\section{Penerapan Metode Mamdani}

Pada Penelitian ini, yang ditetapkan sebagai masukan (input) adalah atribut Penjualan dan Persediaan, sementara yang menjadi keluaran (output) adalah Pembelian. Sebagai misal, diketahui Penjualan ayam potong (maksudnya setelah digoreng) dan Persediaan ayam potong masing masing sebanyak tertentu, bagaimana menentukan jumlah ayam potong Pembelian yang harus dilakukan?. Pertanyaan ini akan dijawab menggunakan Metode Mamdani dengan langkah langkah sebagai berikut:

1. Fuzzyfikasi yaitu mengubah nilai crisp keanggotaan menjadi derajat keanggotaan, misalnya berapakah derajat keanggotaan atribut Persediaan ketika jumlah Persediaan 15 ekor? Jawabnya adalah derajat keanggotaan SEDIKIT $\frac{15-10}{25}=\frac{1}{5}$ dan derajat keanggotaan BANYAK $\frac{35-15}{25}=\frac{4}{5}$. Demikian juga untuk Atribut lainnya.

\section{Pembentukan Aturan Fuzzy}

Aturan Fuzzy (Fuzzy Rule) untuk Metode Mamdani dilakukan menggunakan operasi logika AND pada aturan IF-THEN. Untuk kasus Rumah Makan ayam goreng ini pembentukan aturan fuzzynya adalah 4 aturan (Rule) sebagai berikut:

$\left[\boldsymbol{R}_{1}\right]$ IF Penjualan TURUN AND Persediaan BANYAK THEN Pembelian BERKURANG $\left[\boldsymbol{R}_{\mathbf{2}}\right] \boldsymbol{I F}$ Penjualan TURUN $\boldsymbol{A N D}$ Persediaan SEDIKIT THEN Pembelian BERKURANG $\left[\boldsymbol{R}_{\mathbf{3}}\right] \boldsymbol{I F}$ Penjualan NAIK $\boldsymbol{A N D}$ Persediaan BANYAK $\boldsymbol{T H} \boldsymbol{E N}$ Pembelian BERTAMBAH 
$\left[\boldsymbol{R}_{\mathbf{4}}\right] \boldsymbol{I F}$ Penjualan NAIK AND Persediaan SEDIKIT THEN Pembelian BERTAMBAH Aturan (Rule) ini dapat ditabulasi seperti Tabel 2 sebagai berikut:

Tabel 2. Hubungan antar Persediaan, Penjualan dengan Pembelian dalam Rule IF-THEN

\begin{tabular}{|c|c|c|c|c|}
\hline & \multirow{2}{*}{\multicolumn{2}{|c|}{ Penjualan }} & \\
\hline & & & & \\
\hline & & Turun (0) & Naik (1) & \\
\hline \multirow[t]{2}{*}{ Persediaan } & $\begin{array}{l}\text { Sedikit } \\
\text { (0) }\end{array}$ & Berkurang (00) & Bertambah (01) & \multirow[t]{2}{*}{ Pembelian } \\
\hline & $\begin{array}{l}\text { Banyak } \\
\text { (1) }\end{array}$ & Berkurang (10) & Bertambah (11) & \\
\hline & & \multicolumn{2}{|c|}{ Pembelian } & \\
\hline
\end{tabular}

Sumber: Berdasarkan Rule Fuzzy Logic

Perhatikan bahwa untuk membuat banyaknya Rule yang diperlukan, sangat tergantung pada banyaknya variabel dari kedua input. Dalam kasus Rumah Makan ini kedua inputnya masing masing terdiri atas dua variabel sehingga Rulenya ada sebanyak empat seperti yang telah dinyatakan dan dalam Tabel 2. Jadi sekiranya atribut Linguistik Penjualan ditambah menjadi TURUN, NORMAL, NAIK dan Persediaan ditambah menjadi SEDIKIT, SEDANG, BANYAK, maka banyaknya Rule yang diperlukan adalah sebanyak sembilan untuk mendapatkan keluaran (output) Pembelian.

3. Implikasi

Implikasi digunakan untuk menganalisis logika fuzzy dengan metode fungsi MIN, atau dengan rumus A AND B = MIN(A,B).

4. Agregasi/Komposisi

Agregasi mencari nilai MAX dari himpunan seluruh nilai MIN, atau dengan rumus MAX = MAX dari MIN(MIN1, MIN2,...,.MINn)

5. Defuzzyfikasi

Defuzzyfikasi adalah proses menghitung nilai crisp keanggotaan yang dicari berdasarkan nilai MAX pada Agregasi/Komposisi. Metode Mamdani mencari nilai Centroid dari luas grafik fungsi Pembelian dengan batas derajat keanggotaan MAX tersebut. Berikut ini diperlihatkan proses perhitungan Centroid metode Mamdani untuk input Penjualan 60 ekor dan 80 ekor dan input Persediaan 15 ekor dan 30 ekor. Proses perhitungannya adalah sebagai berikut:
1. $\mu_{N}(80)=\frac{100-80}{50}=\frac{2}{5} \quad ; \mu_{T}(80)=\frac{80-50}{50}=\frac{3}{5}$
2. $\mu_{N}(60)=\frac{100-60}{50}=\frac{4}{5} \quad ; \mu_{T}(60)=\frac{60-50}{50}=\frac{1}{5}$
3. $\mu_{B}(15)=\frac{35-15}{25}=\frac{4}{5} \quad ; \mu_{S}(15)=\frac{15-10}{25}=\frac{1}{5}$
4. $\mu_{B}(30)=\frac{35-30}{25}=\frac{1}{5} \quad ; \mu_{S}(30)=\frac{30-10}{25}=\frac{4}{5}$

Kasus I adalah $\mu_{N}(80)$ AND $\mu_{B}(15)=\frac{2}{5} ; \mu_{N}(80)$ AND $\mu_{S}(15)=\frac{1}{5} ; \mu_{T}(80)$ AND $\mu_{B}(15)=\frac{3}{5} ; \mu_{T}(80)$ AND $\mu_{S}(15)=\frac{1}{5}$.

Dari keempat data ini yakni $\frac{2}{5}, \frac{1}{5}, \frac{3}{5}, \frac{1}{5}$ nilai MAX $=\frac{3}{5}$

Kasus II adalah $\mu_{N}(80)$ AND $\mu_{B}(30)=\frac{1}{5} ; \mu_{N}(80)$ AND $\mu_{S}(30)=\frac{2}{5} ; \mu_{T}(80)$ AND $\mu_{B}(30)=\frac{1}{5} ; \mu_{T}(80)$ AND $\mu_{S}(30)=\frac{3}{5}$.

Dari keempat data ini yakni $\frac{1}{5}, \frac{2}{5}, \frac{1}{5}, \frac{3}{5}$ nilai $\mathrm{MAX}=\frac{3}{5}$ 
Kasus III adalah $\mu_{N}(60)$ AND $\mu_{B}(15)=\frac{4}{5} ; \mu_{N}(60)$ AND $\mu_{S}(15)=\frac{1}{5} ; \mu_{T}(60)$ AND $\mu_{B}(15)=\frac{1}{5} ; \mu_{T}(60)$ AND $\mu_{S}(15)=\frac{1}{5}$.

Dari keempat data ini yakni $\frac{4}{5}, \frac{1}{5}, \frac{1}{5}, \frac{1}{5}$ nilai MAX $=\frac{4}{5}$

Kasus IV adalah $\mu_{N}(60)$ AND $\mu_{B}(30)=\frac{1}{5} ; \mu_{N}(60)$ AND $\mu_{S}(30)=\frac{4}{5} ; \mu_{T}(60)$ AND $\mu_{B}(30)=\frac{1}{5} ; \mu_{T}(60)$ AND $\mu_{S}(30)=\frac{4}{5}$.

Dari keempat data ini yakni $\frac{1}{5}, \frac{4}{5}, \frac{1}{5}, \frac{4}{5}$ nilai MAX $=\frac{4}{5}$

Dari hasil perhitungan ini besarnya Pembelian pada Kasus I, Kasus II, Kasus III dan Kasus IV dapat dihitung sebagai berikut::

\section{Kasus I dan Kasus II}

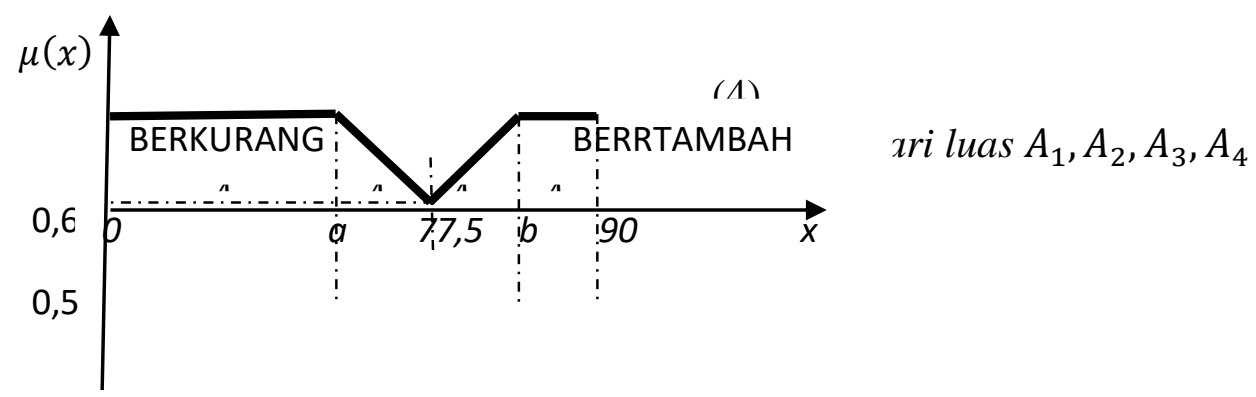

Gambar 7. Grafik Pembelian pada Kasus I dan Kasus II

Perhatikan bahwa nilai $a$ dan $b$ pada Gambar 7 dapat dihitung menggunakan persamaan (4) yaitu $0,6=\frac{b-65}{25}$ diperoleh $b=80,0,6=\frac{90-a}{25}$ diperoleh $a=75$

Jadi luas dari $A_{1}=0,6 \times 75=45, A_{2}=\frac{1}{2}(0,6+0,5)(77,5-75)=1,37, A_{3}=\frac{1}{2}(0,6+$ $0,5)(80-77,5)=1,37$, dan $A_{2}=0,6 x(90-80)=6$.

$A_{1}+A_{2}+A_{3}+A_{4}=53,74$

Selanjutnya hitung nilai Momentum setiap fungsi:

$M_{1}=\int_{0}^{75} 0,6 x d x=0,3\left(75^{2}-0\right)=1.687,5$

$M_{2}=\int_{75}^{77,5}\left(\frac{90-x}{25}\right) x d x=\frac{9}{5}\left(77,5^{2}-75^{2}\right)-\frac{1}{75}\left(77,5^{3}-75^{3}\right)=104,79$

$M_{3}=\int_{77,5}^{80}\left(\frac{x-65}{25}\right) x d x=\frac{1}{75}\left(80^{3}-77,5^{3}\right)-\frac{13}{10}\left(80^{2}-77,5^{2}\right)=-289,47$

$M_{4}=\int_{80}^{90} 0,6 x d x=0,3\left(90^{2}-80^{2}\right)=510$

$M_{1}+M_{2}+M_{3}+M_{4}=2.012,82$

Kasus I and Kasus II Centroid Point of Mamdani Method:

$x=\frac{M_{1}+M_{2}+M_{3}+M_{4}}{A_{1}+A_{2}+A_{3}+A_{4}}=\frac{2.012,82}{53,74}=38$ ekor 


\section{Kasus III dan Kasus IV}

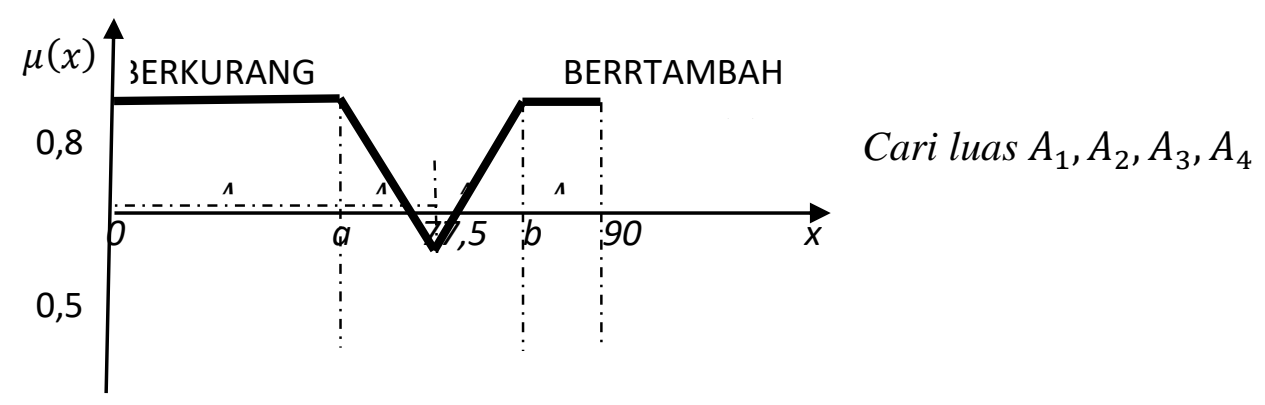

Gambar 7. Grafik Pembelian pada Kasus III dan Kasus IV

Perhatikan bahwa nilai $a$ dan $b$ pada Gambar 7 dapat dihitung menggunakan persamaan (4) yaitu $0,8=\frac{b-65}{25}$ diperoleh $b=85,0,8=\frac{90-a}{25}$ diperoleh $a=70$

Jadi luas dari $A_{1}=0,8 \times 70=56, A_{2}=\frac{1}{2}(0,8+0,5)(77,5-70)=4,83, A_{3}=\frac{1}{2}(0,8+$ $0,5)(85-77,5)=4,83$, dan $A_{4}=0,8 x(90-80)=8$.

$A_{1}+A_{2}+A_{3}+A_{4}=73,66$

Selanjutnya hitung nilai Momentum setiap fungsi:

$M_{1}=\int_{0}^{70} 0,8 x d x=0,4\left(70^{2}-0\right)=1.960$

$M_{2}=\int_{70}^{77,5}\left(\frac{90-x}{25}\right) x d x=\frac{9}{5}\left(77,5^{2}-70^{2}\right)-\frac{1}{75}\left(77,5^{3}-70^{3}\right)=358,13$

$M_{3}=\int_{77,5}^{85}\left(\frac{x-65}{25}\right) x d x=\frac{1}{75}\left(85^{3}-77,5^{3}\right)-\frac{13}{10}\left(85^{2}-77,5^{2}\right)=397,5$

$M_{4}=\int_{85}^{90} 0,8 x d x=0,4\left(90^{2}-85^{2}\right)=350$

$M_{1}+M_{2}+M_{3}+M_{4}=3.065,63$

Kasus III and Kasus IV Centroid Point of Mamdani Method:

$x=\frac{M_{1}+M_{2}+M_{3}+M_{4}}{A_{1}+A_{2}+A_{3}+A_{4}}=\frac{3.065,63}{73,66}=42$ ekor

\section{HASIL PENELITIAN DAN PEMBAHASAN}

Dari hasil perhitungan diatas dapat dilakukan tabulasi seperti Tabel 3.

Tabel 3. Hasil Perhitungan Pembelian Metode Mamdani untuk 4 Kasus

\begin{tabular}{|c|c|c|c|c|}
\hline $\begin{array}{l}\text { KASU } \\
\text { S }\end{array}$ & $\begin{array}{l}\text { PENJUALA } \\
\mathrm{N} \text { (ekor) }\end{array}$ & $\begin{array}{l}\text { PERSEDIAA } \\
\mathrm{N} \\
\quad \text { (ekor) }\end{array}$ & $\begin{array}{l}\text { PEMBELIA } \\
\mathrm{N} \\
\quad \text { (ekor) }\end{array}$ & $\begin{array}{c}\text { PERSEDIAAN+PEMBELIA } \\
\mathrm{N} \\
\text { (ekor) }\end{array}$ \\
\hline I & 80 & 15 & 38 & 53 \\
\hline II & 80 & 30 & 38 & 68 \\
\hline III & 60 & 15 & 42 & 57 \\
\hline IV & 60 & 30 & 42 & 72 \\
\hline
\end{tabular}

Sumber: Hasil perhitungan sendiri

Untuk mendapatkan hasil perhitungan output Pembelian untuk berbagai nilai keanggotaan Penjualan dan Persediaan sebagai input, dapat digunakan program aplikas fuzzy logic FIS (Fuzzy Inference System). Perhatikan bahwa pada Tabel 3 jumlah Persediaan ditambahkan 
dengan jumlah Pembelian seharusnya minimal sama dengan jumlah Penjualan. Anggapan demikian keliru, sebab jumlah Penjualan tersebut hanyalah perkiraan teoritis. Hasil perhitungan pada Tabel 3 tidak boleh bertentangan dengan isi Tabel 1 yang minimal dibutuhkan sebanyak 50 ekor yang terjadi pada hari Kamis 7 Februari 2019. Hasil perhitungan pada Tabel 3 memperlihatkan Persediaan ditambah Pembelian minimal 53 ekor yang memenuhi dan lebih besar dari 50 ekor keadaan minimal pada Tabel 1.

\section{KESIMPULAN}

\section{Simpulan}

Rancangan fungsi keanggotaan dari tiga atribut linguistik yang masing masing terdiri atas dua variabel linguistik: Persediaan(Sedikit, Banyak), Penjualan (Turun, Naik), dan Pembelian (Berkurang, Bertambah) pada Rumah Makan "Ayam Goreng Murah Rezeki” memberikan hasil perhitungan yang sesuai pada kisaran yang diperkirakan menggunakan metode Mamdani.

\section{Saran}

1. Penelitian ini dapat dilanjutkan dengan meningkatkan jumlah variabel linguistik pada masing masing atribut linguistik menjadi misalnya masing masing tiga variabel sehingga hasil yang diperoleh lebih teliti.

2. Rancangan fungsi keanggotaan dapat dipilih model grafik yang lain, dan dengan metode yang lain: Metode Tsukamoto atau Metode Sugeno.

\section{DAFTAR PUSTAKA}

Dewi, K., \& Hari, S. P. (2010). Aplikasi Logika Fuzzy (Fuzzy Inference System). Yogyakarta: Graha Ilmu.

S, H. (1999). Forecasting and Simulation of Net Inflows for Reservoir Operation and Management. Malaysia: Universiti Teknologi Malaysia.

Setiadi. (2009). Himpunan dan Logika Samar serta Aplikasinya. Yogyakarta: Graha Ilmu.

Suardika, K. K., \& dkk. (2018). Perbandingan Metode Tsukamoto, Metode Mamdani dan Metode Sugeno untuk Menentukan Produksi Dupa. E-Jurnal Matematika 7(2), 180186.

Susilo, \& SJ, F. (2006). Himpunan dan Logika Kamur serta Aplikasinya. Yogyakarta: Graha Ilmu. 